Preliminary communication

\title{
EFFECT OF DIFFERENT ECOLOGICAL CONDITIONS ON CONTENT OF PHYTONUTRIENTS IN INDUSTRIAL TOMATOES
}

\author{
Sz. RÁth ${ }^{\mathrm{a} *}$, M. ÉGEI ${ }^{\mathrm{a}}$, K. Horvátha ${ }^{\mathrm{a}}$ B. ANDRYIE and H. G. DAOOD \\ aSzent István University, Institute of Horticultural Technology, Gödöllő \\ ${ }^{\text {bS }}$ zent István University, Regional Knowledge Center, Gödöllő \\ (Received: 4 July 2019; accepted: 17 January 2020)
}

\begin{abstract}
Tomatoes (Solanum lycopersicon L.) are one of the most important and most widely consumed vegetables in the world. The fruit contains considerable amount of different phytonutrients such as carotenoids, tocopherols, and vitamin C. In the present work, effects of some abiotic factors on the concentration of phytonutrients were investigated in tomato cultivated in two different types of soil. It was found that the type of soil had slight effect on the most important vital nutrients, while the ecological factors, particularly precipitation and average temperature 3 weeks before harvest, were of significant influence on such nutrients. It was found that low temperature and high precipitation before harvest caused the levels of carotenoids, tocopherol, and vitamin $\mathrm{C}$ to significantly increase by $65 \%, 46 \%$, and $28 \%$, respectively.
\end{abstract}

Keywords: carotenoids, tocopherols, vitamin C, tomato, HPLC, abiotic factors

Tomato (Solanum lycopersicon L.) and its products can play a significant role in modern human diet as important sources of vitamins, minerals, and antioxidants as well as their being relatively easily accessible foods. It is consumed in many forms, such as fresh, cooked, condensed, and dried. Tomato fruit contains considerable amounts of valuable phytochemicals, which raise the nutritional importance of tomatoes and increase their use as functional food or food ingredient. Among phytochemicals, carotenoids (lycopene, $\beta$-carotene) are of special interest due to their role in reduction of the onset of several types of cancer (GIOvANNUCCI, 1999) and cardiovascular (GAMMONE et al., 2015) or neurodegenerative diseases (RAO \& RAO, 2007).

In case of industrial tomatoes, the factors that influence the concentration of phytonutrients such as carotenoids, tocopherols, and vitamin $\mathrm{C}$ the most, may include the maturity level of fruit at the time of harvest and agronomic, geographical, and environmental conditions (LeNUCCI et al., 2006; HelYes et al., 2006; IlAHY et al., 2011; HeLYES et al., 2014; De Sio et al., 2019). The nutritional value of tomato can be optimized by providing the right environmental parameters, such as choosing the right crop area (MEULEBROKE et al., 2012), and measures to compensate for weather extremes (such as watering or shading). Both temperature and light are the most significant factors in the synthesis of antioxidant carotenoid compounds, and above $30-32^{\circ} \mathrm{C}$, for example, the formation of lycopene is inhibited (DumAS et al., 2003; HeLYES, 2007), but $\beta$-carotene synthesis still happens. It remains active up to 38

\footnotetext{
* To whom correspondence should be addressed.

E-mail: rath.szilvia@mkk.szie.hu
} 
${ }^{\circ} \mathrm{C}$, which can result in a change in the colour of the berries. Further abiotic factors that determine temperature and UV-B radiation are precipitation and soil. Soils with different properties also have a significant impact on the quality of the crop and its content parameters.

In Hungary, industrial tomato is cultivated in different soil types including sand and clay-loam soils. The two most widely used soil types are suitable for the production of industrial tomatoes, but their different agronomic properties may lead to differences in tomato's nutritional value. Earlier studies have shown that water stress causes the lycopene levels of tomato fruit to rise (Dumas et al., 2003). The weather parameters, the appropriate crop area, and other great influencers can play significant roles in the cultivation (HELYES, 1999) and ultimately the developmental parameters of this vegetable species, such as water soluble solids, carbohydrates, acid content, amount and proportion of phytonutrients (HELYES, 2007).

The main objective of the present work was to study the effect of soil type and some abiotic factors on the content of the most important phytonutrients in industrial tomato cultivated in 2017 and 2018 seasons.

\section{Materials and methods}

\subsection{Experimental material}

The examined processing tomato was UG812 J hybrid, which was provided by OROSCO Ltd. (United Genetics Seeds Co., Hollister, California, USA). The processing tomato was cultivated in two locations differing in the type of soil; (1) sandy-loam soil of the experimental field of the Szent István University in Gödöllö, (2) clay-loam soil of the experimental fields of the same university in Szarvas for two consecutive years (2017 and 2018). In 2017, the date of transplantation was June $15^{\text {th }}$ in Szárítópuszta and May $9^{\text {th }}$ in Szarvas. In the following year, the date of transplantation was May $17^{\text {th }}$ in Száritópuszta and May $8^{\text {th }}$ in Szarvas. Both years the plants were irrigated and given the necessary nutrients as required for industrial tomatoes. The berries were harvested at the red ripeness stage (selected based on size and redness) at the end of August from 10 plants to represent one replicate sample. Four replicate samples were taken for different analyses. Each replicate sample was homogenised in a Waring blender and stored at $-20{ }^{\circ} \mathrm{C}$ when not immediately analysed.

\subsection{Soil and climate conditions}

Szárítópuszta is a part of Gödöllö territory, in which the soil is sandy loam characterized as a slightly alkaline brown forest soil ( $41 \%$ sand, $47.5 \%$ silt, and $11.5 \%$ clay). The soil has an Arany's binding value $(\mathrm{Ka})$ between 28 and 42 with low water capacity and high-water absorption and drainage capacity. Sufficient and optimal water supply of the stock was provided by the drip system during the growing season, depending on air temperature. The experiment was carried out in randomised, complete block design in four replications. It was a symmetrical arrangement, where the distance between rows was $150 \mathrm{~cm}$ and the spine was $18.6 \mathrm{~cm}$. The length of the growing season was 100 days for both cultivation seasons and locations. 
The other experimental field of the Szent István University was in Szarvas, where the soil is clay-loam with $37 \%$ clay, $29.4 \%$ sand, $33.6 \%$ sludge fraction, $3 \%$ humus contents and slightly acidic pH (6.68). It is a more bounder soil than that in Szárítópuszta. Due to such composition, the water capacity of the soil is much higher than that of the Gödöllö soil. Due to its lower water absorption and drainage capability, the water supply took longer under the drought summer. The optimal water supply during the growing season was assured. Planting was done in single rows at $140 \mathrm{~cm}$ row and $20 \mathrm{~cm}$ spacing with machine for both years. Table 1 shows the meteorological parameters for the cultivation seasons.

Table 1. Meteorological data during the growing seasons of 2017 and 2018

\begin{tabular}{lcccc}
\hline Meteorological parameters & \multicolumn{2}{c}{ Szárítópuszta } & \multicolumn{2}{c}{ Szarvas } \\
\cline { 2 - 5 } & 2017 & 2018 & 2017 & 2018 \\
\hline Average temperature $\left({ }^{\circ} \mathrm{C}\right)$ & 20.6 & 21.6 & 21.8 & 22.3 \\
Average temperature $\left({ }^{\circ} \mathrm{C}\right) 3$ weeks before harvest & 16.9 & 23.8 & 24.9 & 25.5 \\
Number of days in excess at $32{ }^{\circ} \mathrm{C}$ & 0 & 0 & 12 & 14 \\
Precipitation $(\mathrm{mm})$ & 323.8 & 305 & 146.3 & 126.9 \\
Precipitation $(\mathrm{mm}) 3$ weeks before harvest & 191.8 & 91 & 30.2 & 35.8 \\
\hline
\end{tabular}

\subsection{Chemicals used for chemical analyses}

Analytical and HPLC grade solvents used for the extraction and HPLC determination of phytonutrients were purchased from Merck (Budapest, Hungary). All chemicals used for extraction and HPLC determination of vitamin $\mathrm{C}$ were of analytical grade and purchased from VWR (Debrecen, Hungary). Standard carotenoids, tocopherols, and L-ascorbic acid were purchased from Sigma-Aldrich (Budapest, Hungary).

\subsection{Extraction of carotenoids and tocopherols}

The fat-soluble carotenoids and tocopherols were extracted by a procedure described earlier (DAOOD \& BIACS, 2005). Briefly, 5 grams of a warring blender-homogenised tomato sample was crushed in a crucible mortar with quartz and extracted with methanol and then with 1:5 methanol:dichloroethane. The dichloroethane fraction was separated in a separating funnel after addition of $1 \mathrm{ml}$ water to ensure phase separation. The lower solvent was dried over anhydrous $\mathrm{Na}_{2} \mathrm{SO}_{4}$ into a round-bottom flask and evaporated with a vacuum-controlled evaporator (Ingos RVO-400). The residues were re-dissolved in $5 \mathrm{ml} \mathrm{HPLC}$ acetone and cleaned up by passing through PTFE, $0.22 \mu \mathrm{m}$ syringe filter before injection on to HPLC column.

\subsection{Extraction of vitamin $C$}

Five grams of the well homogenised tomato sample was crushed in a crucible mortar and extracted by $30 \mathrm{ml}$ of $3 \%$ metaphosphoric acid solution with mechanical shaking for $15 \mathrm{~min}$ followed by filtration through a DF 400 filter paper (Albet LabScience, Dassal, Germany). The filtrate was further cleaned up by passing through a Whatman cellulose acetate $0.45 \mu \mathrm{m}$ syringe filter before injection on to HPLC column. 


\subsection{HPLC instrument and conditions}

Hitachi Chromaster HPLC instrument consisting of a Model 5110 Pump, a Model 5430 Diode Array detector, a Model 5440 Fluorescence detector, and a Model 5210 auto-sampler were used. The separation and data processing were operated by EZChrom Elite software. Carotenoids were detected between 190 and $700 \mathrm{~nm}$, while detection of vitamin $\mathrm{C}$ was between 190 and $400 \mathrm{~nm}$ using diode-array detector. Fluorescent detector was adjusted at EX: $295 \mathrm{~nm}$ and EM: $325 \mathrm{~nm}$ for the detection and determination of tocopherols.

Separation of carotenoids was performed on a core C-30, $150 \times 4.6 \mathrm{~mm}, 2.6 \mu \mathrm{m}$ (Thermo Scientific, USA) column with a gradient elution of (A) tert-butyl methyl ether (TBME) in (B) $2 \%$ water in methanol (Under publication LC-MS/MS protocol). The gradient started with $3 \% \mathrm{~A}$ in $\mathrm{B}$, changed to $35 \% \mathrm{~A}$ in $\mathrm{B}$ in $20 \mathrm{~min}$, steady isocratic for $5 \mathrm{~min}$, and finally turned to $3 \% \mathrm{~A}$ in $\mathrm{B}$ in $5 \mathrm{~min}$. The flow rate was $0.6 \mathrm{ml} \mathrm{min}^{-1}$. For quantification, the area of each compound was recorded at the maximum absorbance wavelength. Concentration of carotenoids was calculated as 8 -apo-carotenal equivalent. The internal standard was spiked at known concentration to the samples. Standard materials for lycopene, $\beta$-carotene, and lutein were used for quantitation and identification of such carotenoids. The other carotenoids were tentatively identified based on comparison of their spectral characteristics and retention properties with those from literature (ToNUCCI et al., 1995; ANGUELOVA \& WARTHESEN, 2000; Rodriguez \& Rodriguez-AmaYa, 2007; GURAK et al., 2014).

As for vitamin C, the separation was carried out on Nucleosil C18 aqua Nautilus C8, 3 $\mu \mathrm{m}, 150 \times 4.6 \mathrm{~mm}$ column (Machery Nagel, Düren, Germany) and gradient elution of acetonitrile (A) in a $0.01 \mathrm{M} \mathrm{KH}_{2} \mathrm{PO}_{4}$ at $\mathrm{pH} 4(\mathrm{~B})$. The elution started with $2 \% \mathrm{~A}$ in $\mathrm{B}$, changed to $30 \% \mathrm{~A}$ in $\mathrm{B}$ in $15 \mathrm{~min}$, and turned to $2 \% \mathrm{~A}$ in $\mathrm{B}$ in $5 \mathrm{~min}$ (NAGY et al., 2017). The flow rate was $0.7 \mathrm{ml} \mathrm{min}^{-1}$. The area of L-ascorbic acid was integrated at $265 \mathrm{~nm}$. Identification and quantification was based on use of external standard material injected under the same conditions.

Separation of tocopherols was performed on Nucleosil, C18, $3 \mu \mathrm{m}, 250 \times 4.6 \mathrm{~mm}$ EC column (Macherey Nagel, Düren, Germany) and gradient elution of (A) water, (B) methanol and $(\mathrm{C})$ methanol:2-propanol:acetonitrile 10:55:35. The gradient elution started with $7 \% \mathrm{~A}$ in $\mathrm{B}$, changed to $100 \% \mathrm{~B}$ in $5 \mathrm{~min}$, changed to $5 \% \mathrm{~B}$ and $95 \% \mathrm{C}$ in $25 \mathrm{~min}$, and finally turned to

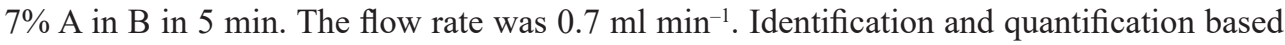
on application of external standard tocopherols.

\subsection{Statistical analysis}

The results are stated as the means of four replicates. For the statistical analysis IBM SPSS statistics data were used as mean value \pm standard deviation. The repeated measures of ANOVA followed by post hoc (Fisher's) test were used for the detailed comparison of measurement data of the four tomato replicate samples.

\section{Results and discussion}

\subsection{Changes in carotenoids}

The newly developed HPLC separation protocol provided excellent separation of the major carotenoids such as lycopene and $\beta$-carotene as well as their geometrical isomers and derivatives (Fig. 1). The present work focused only on all-trans lycopene and $\beta$-carotene due to their special importance from quality and human nutrition points of view.

Acta Alimentaria 49, 2020 


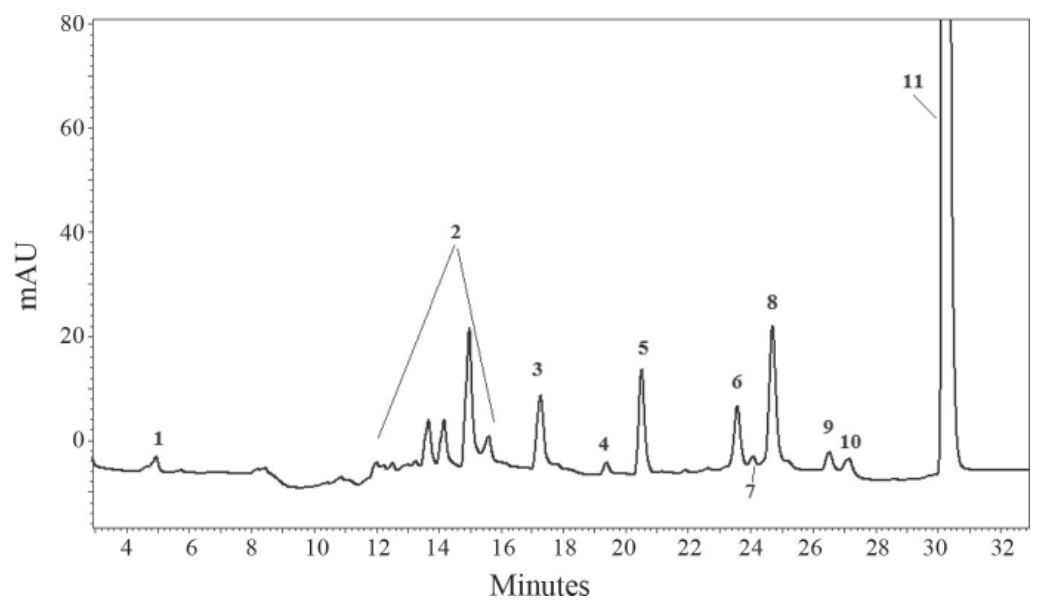

Fig. 1. HPLC profile of tomato carotenoids on C-30, core, $3 \mu \mathrm{m}, 150 \times 4.6 \mathrm{~mm}$ column and gradient elution of TBME in methanol containing $2 \%$ water. For more details see text. 1: lutein; 2 : mono- and di-epoxides of $\beta$-carotene; 3: lycopene epoxide; 4: cis-lycopene derivative; 5: lycoxanthin; 6: $\beta$-carotene; 7: 15-cis-lycopene; 8: 13-cis-lycopene; 9: $\gamma$-carotene; 10: 9-cis-lycopene; 11: all-trans-lycopene

The contents of $\beta$-carotene $(0.23-1.09 \mathrm{mg} / 100 \mathrm{~g})$ and lycopene $(14.8-24.36 \mathrm{mg} / 100 \mathrm{~g} \mathrm{f}$. wt) determined in tomatoes fall in the concentration range found for the same carotenoids in different genotypes (LENUCCI et al., 2006). In 2017, there was a significant difference between tomatoes cultivated in Szárítópuszta and Szarvas in the content of the major carotenoids, particularly $\beta$-carotene $(P<0.01)$. This tendency was true in 2018 but at less significant degree $(\mathrm{P}>0.05)$. It seems that difference found in the content of carotenoids of tomato produced in different soil types is due rather to the effect of temperature, sunshine period, and precipitation before harvest than the type of soil (Figs 2 and 3).

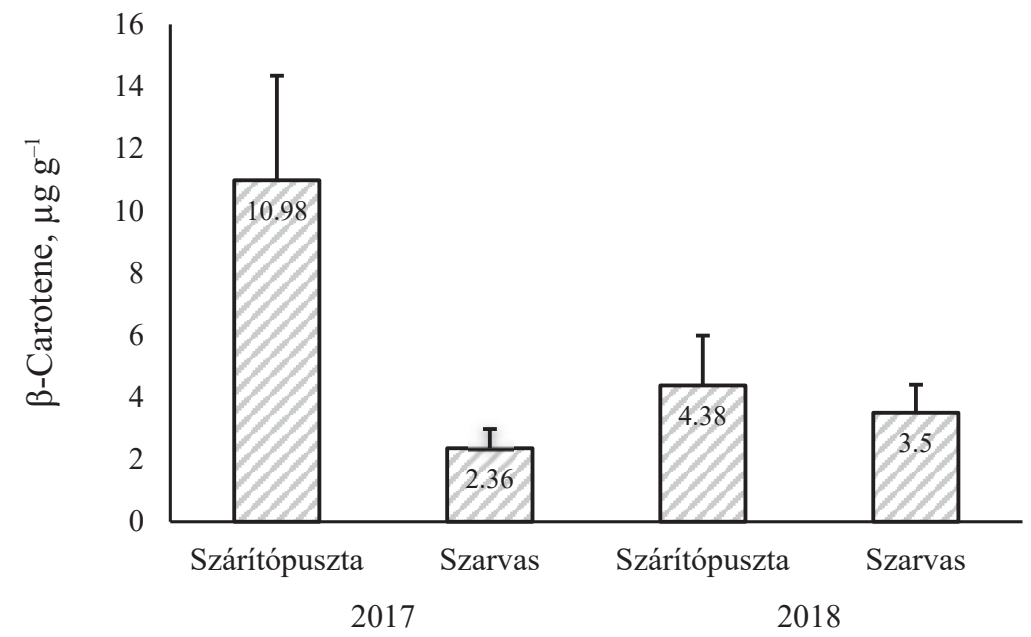

Fig. 2. $\beta$-Carotene content ( $\mu \mathrm{g} \mathrm{g}^{-1}$ f.wt) of tomato cultivated in 2017 and 2018 seasons at two different locations 


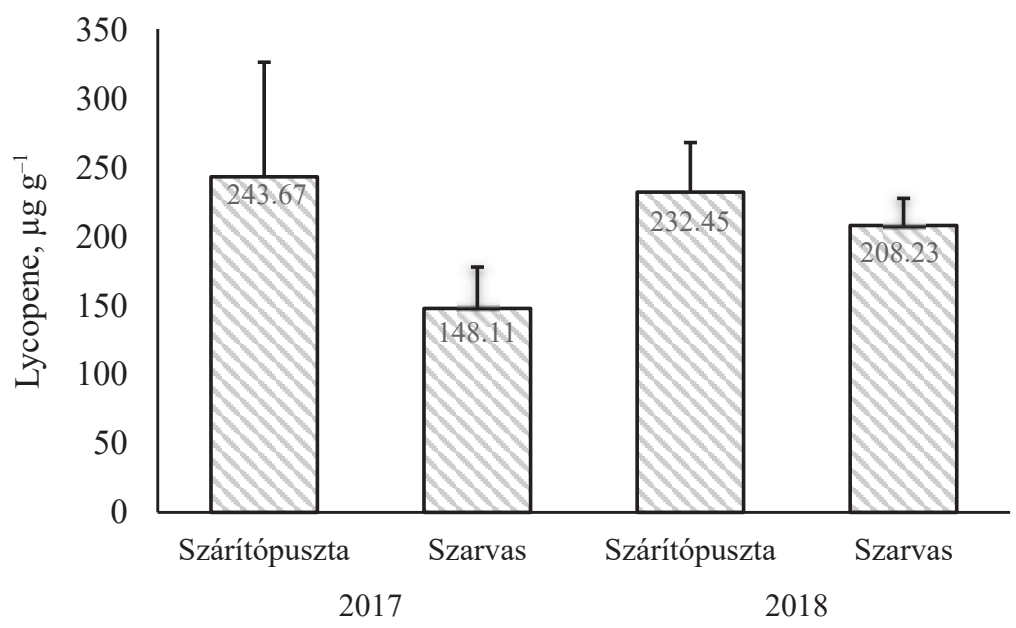

Fig. 3. Lycopene content ( $\mu \mathrm{g} \mathrm{g}^{-1}$ f.wt) of tomato cultivated in 2017 and 2018 seasons at two different locations

The data in Table 1 show that temperature before harvest in Szarvas was substantially higher than in Szárítópuszta. The high air temperature and long sunshine period assist in raising the temperature of the berry surface and might have negative effect on the rate of carotenogenesis. Dumas and co-workers (2003) stated that at $30-32{ }^{\circ} \mathrm{C}$, the formation of lycopene is inhibited. It has been found that the synthesis of $\beta$-carotene is inhibited only above $38^{\circ} \mathrm{C}$ and if the temperature is between 32 and $38^{\circ} \mathrm{C}$, change of lycopene to $\beta$-carotene is promoted via lycopene $\beta$-cyclase enzyme (PÉK et al., 2011).

\subsection{Changes in tocopherols}

Figure 4 shows the HPLC profile of tomato tocopherols. The biologically active form of vitamin E, $\alpha$-tocopherol, occurred free and esterified (acylated) in addition to the oxidised form $\alpha$-tocopherol quinone, which is formed as a consequence of biochemical oxidation during ripening and after harvest. These forms were abundant in the unsaponified lipid fraction of tomato fruit, while minor quantities of $\gamma$ - and $\beta$-tocopherols and their acylated forms could be detected. Determined by the reversed phase separation procedure, the maximum concentration of the total forms of $\alpha$-tocopherol was $27-35 \mu \mathrm{g} \mathrm{g}^{-1}$ f.wt (equal to $\left.363-583 \mu \mathrm{g} \mathrm{g}^{-1} \mathrm{~d} . w \mathrm{t}\right)$ in tomato cultivated in sandy-loam soils. This range is higher than the 89-398 $\mu \mathrm{g} \mathrm{g}^{-1} \mathrm{~d}$.wt determined by SGHERRI and co-workers (2007) and the 30-290 $\mu \mathrm{g} \mathrm{g}^{-1}$ d.wt found by LENUCCI and co-workers (2006) in ripe red berries of some tomato cultivars. Furthermore, RAIOLA and co-workers (2015) reported that much lower levels of tocopherols have been found in ripe berries of different vegetable tomatoes.

Before harvest, temperature affected the content of the different forms of $\alpha$-tocopherol (free and esterified) similarly to its effect on carotenoids (Fig. 5). Such similarity in behaviour is expected since carotenoids and tocopherols are lipid-soluble compounds and are synthesized by the same pathway in the membranes of the plant chromoplastids (PennA \& Pogson, 2006). 


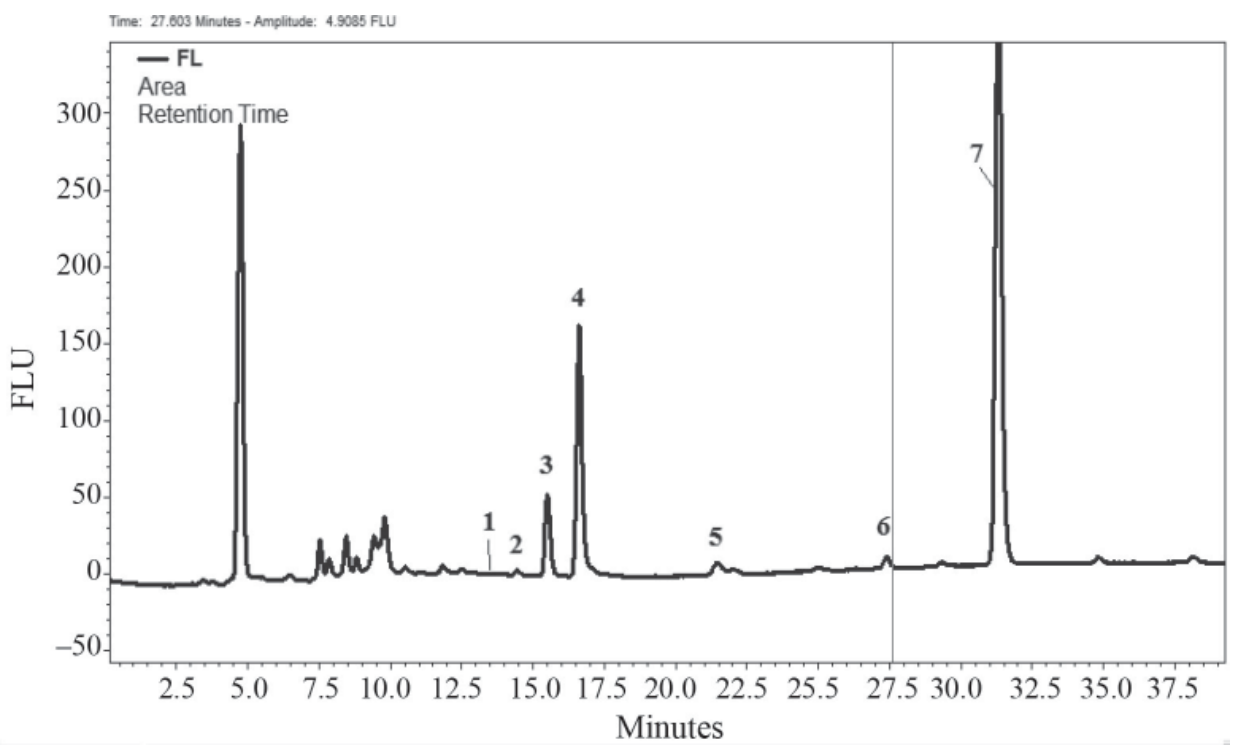

Fig. 4. HPLC profile of tomato separated on Nucleosil C18, ec, $3 \mu \mathrm{m}, 250 \times 4.6 \mathrm{~mm}$ column with gradient elution of methanol, 2-propanol, acetonitrile (10:55:35) in 7\% water in methanol, see text. 1: $\gamma$-tocopherol; 2: $\beta$-tocopherol; 3: $\alpha$-tocopherol quinone; 4: $\alpha$-tocopherol; $5: \gamma$-tocopherol ester; $6: \beta$-tocopherol ester; 7 : $\alpha$-tocopherol ester

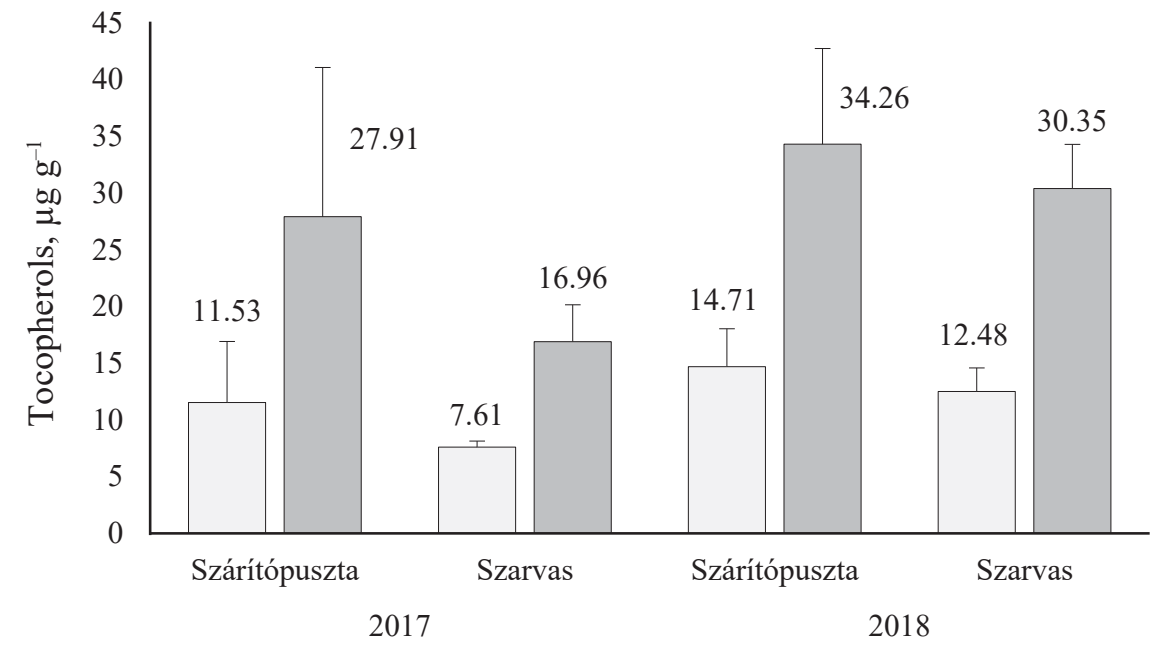

Fig. 5. Change in content ( $\mu \mathrm{g} \mathrm{g}^{-1}$ f.wt) of tocopherols as a function of geographical location and seasonal variations in tomato berries cultivated in 2017 and 2018

$$
\square: \alpha \text {-tocopherol; }: \text { : } \text { Stocopherol }
$$




\subsection{Changes in vitamin $C$}

Regarding vitamin $\mathrm{C}$ content of tomato, the highest level determined in tomato berries examined is close to the average value found for vitamin $\mathrm{C}$ in most cherry and highly pigmented ripe tomato varieties (LENUCCI et al., 2006). It is clear that the seasonal variation has greater influence on vitamin C content than the soil type. In 2017, tomato plants cultivated in Szárítópuszta (sandy loam soil) yielded berries containing higher contents of vitamin C than those cultivated in clay-loam soil (Szarvas) $(\mathrm{P}<0.05)$. The increase in vitamin $\mathrm{C}$ level is most probably due to a decrease in the average temperature and increase of precipitation 3 weeks before harvest (Table 1). In 2018, there was no significant difference between the tomato berries from the different locations in their vitamin C content. Since there was no substantial difference between the two locations in the average temperature 3 weeks before harvest, the remarkably low level of vitamin $\mathrm{C}$ can be explained by the decrease of precipitation before harvest, which was two times less in Száritópuszta in the season of 2018 compared to that in 2017, which was a decrease from 191 to $91 \mathrm{~mm}$ (Fig. 6).

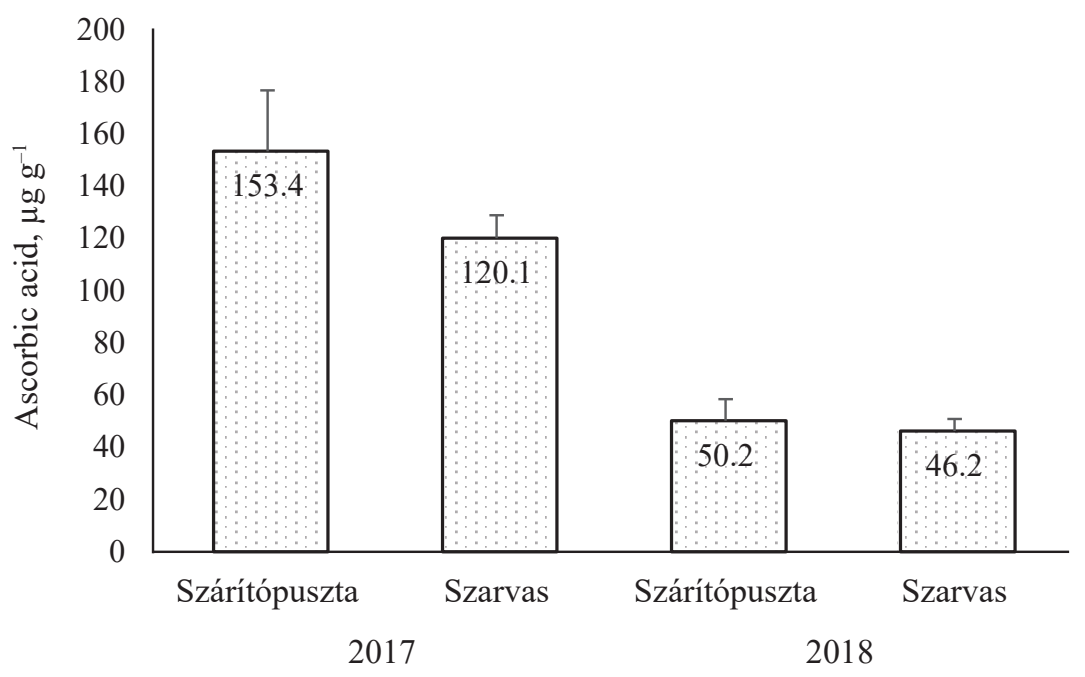

Fig. 6. Changes in contents ( $\mu \mathrm{g} \mathrm{g}^{-1}$ f.wt.) of vitamin $\mathrm{C}$ as a function of soil type and seasonal variations in tomato berries cultivated in 2017 and 2018

\section{Conclussions}

Based on the obtained results, it can be concluded that quality of processing tomatoes can be affected by the abiotic factors such as temperature and precipitation prior to harvest rather than by soil type of the cultivation location, which only has a slight effect. The abiotic factors either promote or inhibit the biosynthesis of different phytonutrients. The high temperature and low precipitation before harvest are not favourable environmental factors for production of high quality and nutrient-rich industrial tomatoes. It is also concluded that high water supply is needed for the biosynthesis of the most important phytonutrients, particularly vitamin $\mathrm{C}$. The negative effect of some abiotic factors may be moderated by modifying the cultivation parameters such as irrigation, shielding, and soil composition. 
The work is supported by the EFOP3.6.3-VEKOP-16-2017-00008 and EFOP-3.6.1-16-201600016 projects. These projects are co-financed by the Higher Education Institutional Excellence Program (1783-3/2018/FEKUTSRAT) awarded by the Ministry of Human Capacities within the framework of water related researches of Szent István University.

\section{References}

Anguelova, T. \& Warthesen, J. (2000): Lycopene stability in tomato powders. J. Food Sci., 6, 67-70.

DAood, H.G. \& BiACs, P.A. (2005): Simultaneous determination of Sudan dyes and carotenoids in red pepper and tomato products by HPLC. J. Chromatogr. Sci., 43, 461-465.

De Sio, F., Rapacciuolo, M., De Giorgi, A., Trifiró, A., Giullano, B., ... \& Caruso, G. (2019): Yield, quality, antioxidant, and sensorial properties of diced tomato as affected by genotype and industrial processing in Southern Italy. Acta Alimentaria, 48, 132-141.

Dumas, Y., Dadomo, M., Giuseppe, D.L. \& Grolie, P. (2003): Effects of environmental factors and agricultural techniques on antioxidant content of tomatoes. J. Sci. Food Agr., 83, 369-382.

Gammone, M.A., Riccioni, G. \& D’Orazio, N. (2015): Carotenoids: Potential allies of cardiovascular health? Food Nutr. Res., 59, 2676-2679.

Giovannucci, E. (1999): Tomatoes, tomato-based products, lycopene, and cancer: Review of the epidemiologic literature. J. Natl Cancer I., 91, 17-22.

GuraK, P.D., Mercedente, A.Z., González-Miret, M.L., Heredia, F.J. \& Meléndez-Martinez, A.J. (2014): Changes in antioxidant capacity and colour associated with the formation of $\beta$-carotene epoxides and oxidative cleavage derivatives. Food Chem., 147, 160-169.

Helyes, L. (1999): A paradicsom és termesztése. (Tomato and its growing). SYCA Szakkönyvszolgálat, Budapest, 233 pages + supplement

Helyes, L. (2007): A paradicsom (Lycopersicon lycopersicum (L.) Karsten) termésképzésére ható abiotikus és biotikus tényezök értékelése különös tekintettel a beltartalmi összetevökre. (Evaluation of abiotic and biotic factors affecting the fruit formation of tomato) HAS Dissertation. 172 pages.

Helyes, L., Dimény, J., PÉK, Z. \& Lugasi, A. (2006): Effect of maturity stage on content, color and quality of tomato (Lycopersicon lycopersicum (L.) Karsten) fruit. Int. J. Hortic. Sci., 12, 41-44.

Helyes, L., Lugasi, A., DaOod, H.G. \& PÉK, Z. (2014): The simultaneous effect of water supply and genotype on yield quantity, antioxidants content and composition of processing tomatoes. Not. Bot. Hort. Agrobot. Cluj, 42(1), 143-149.

Helyes, L., Lugasi, A. \& PÉK, Z. (2007): Effect of natural light on surface temperature and lycopene content of vine ripened tomato fruit. Can. J. Plant Sci., 87, 927-929.

Ilahy, R., Hdider, C., Lenucci, M.S., Tlili, I. \& Dalessandro, G. (2011): Antioxidant activity and bioactive compound changes during fruit ripening of high-lycopene tomato cultivars. J. Agr. Food Chem., 24, 588-595.

Lenucci, M.S., Cadinu, D., Taurino, M., Piro, G. \& Dalessendro, G. (2006): Antioxidant composition in cherry and high-pigment tomato cultivars. J. Agr. Food Chem., 54, 2606-2613.

Meulebroek, L.V., Vanhaecke, L., Swaef, T.D., Steppe, K. \& Brabander, H.D. (2012): U-HPLC-MS/MS to quantify liposoluble antioxidants in red-ripe tomatoes, grown under different stress levels. J. Agr. Food Chem., $60,566-573$.

Nagy, Zs., Daood, H.G., Koncsek, A., Molnár, H. \& Helyes, L. (2017): The simultaneous determination of capsaicinoids, tocopherols, and carotenoids in pungent pepper powder. J. Liq. Chromatogr. R. T., 40(4), 199209.

Pék, Z., Szuvandzsiev, P., Neményi, A., Helyes, L. \& Lugasi, A. (2011): The effect of natural light on changes in antioxidant content and color parameters of vine-ripened tomato (Solanum lycopersicum L.) fruits. HortScience, 46, 583-585.

Penna, D.D. \& Pogson, B.J. (2006): Vitamin synthesis in plants: Tocopherols and carotenoids. Ann. Rev. Plant Biol., 57, 711-749.

Raiola, A., Tenore, G.C., Barone, A., Frusciante, L. \& Rigano, M.M. (2015): Vitamin E content and composition in tomato fruits: Beneficial roles and bio-fortification (review) Int. J. Mol. Sci., 16, 29250-29264.

RaO, A.V. \& RaO, L.G. (2007): Carotenoids and human health. Pharmacol. Res., 55, 207-216. 
Rodriguez, E.B. \& Rodriguez-AmaYA, D.B. (2007): Formation of apocarotenals and epoxycarotenoids from $\beta$-carotene by chemical reactions and by autoxidation in model systems and processed foods. Food Chem., $101,563-572$.

Sgherri, C., Navari-Izzo, F., Pardossi, A., Soressi, P. \& Izzo, R. (2007): The influence of diluted seawater and ripening stage on the content of antioxidants in fruits of different tomato genotypes. J. Agr. Food Chem., 55, 2452-2458.

Tonucci, L.H, Holden, J.M., Beecher, G.R., KhachiK, F., Davis, C.S. \& Mulokozi, G. (1995): Carotenoid content of thermally processed tomato-based food products. J. Agr. Food Chem., 33, 579-586.

Open Access statement. This is an open-access article distributed under the terms of the Creative Commons Attribution 4.0 International License (https://creativecommons.org/licenses/by/4.0/), which permits unrestricted use, distribution, and reproduction in any medium, provided the original author and source are credited, a link to the CC License is provided, and changes - if any - are indicated. (SID_1)

Acta Alimentaria 49, 2020 